Dept. of Food Hygiene, Port-Said Lab., Animal Health Research Institute, Dokki, Giza, Egypt.

\title{
ASSESSMENT OF ALUMINIUM RESIDUES IN MEAT COOKED IN ALUMINIUM UTENSILS
}

(With 3 Tables)

\author{
By
}

\author{
AZZA A. EL-TABIY \\ (Received at $1 / 6 / 2010$ )
}

\section{تقدير نسبة بقايا عنصر الألومنيوم فى اللحوم المطهية فى أوعية الألومنيوم

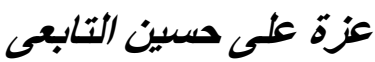

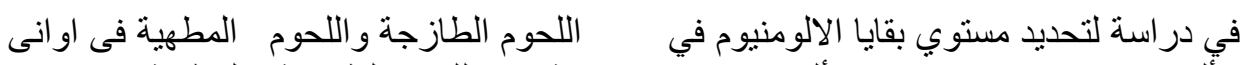

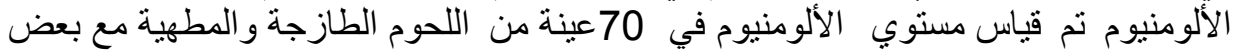

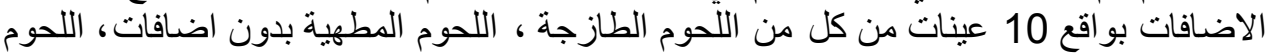

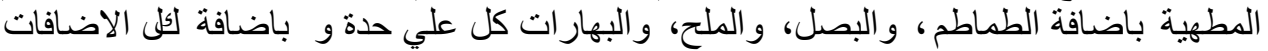

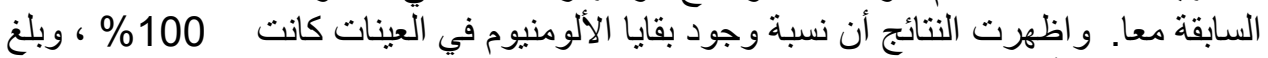

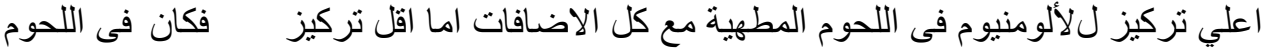

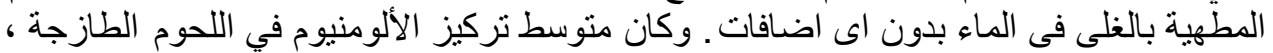

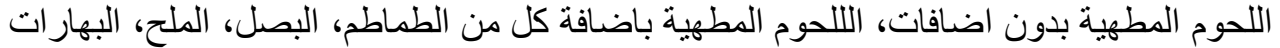

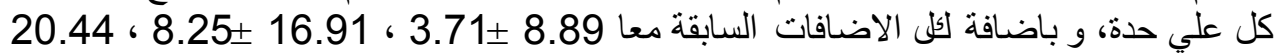

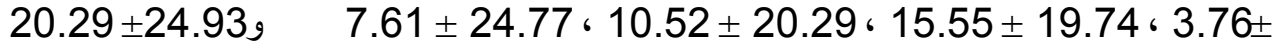

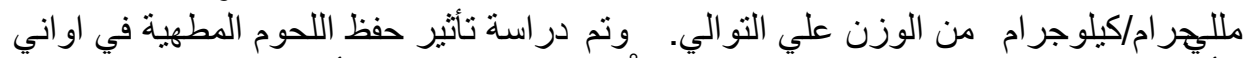

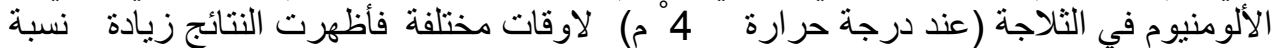

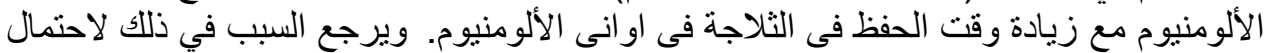

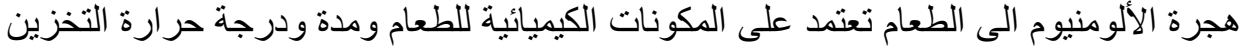

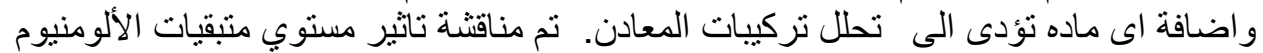

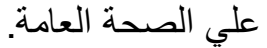

\section{SUMMARY}

Seventy samples of raw meat and meat with different additives cooked in aluminium utensils were investigated for aluminium residues (10 samples each of raw meat, boiled meat either alone or with tomato, onion, salt, spices aswellas with mixing of all the previous additives). Aluminium residues was detected in $100 \%$ of the specimens. The highest concentration was detected in meat cooked with all additives while the low concentration was detected in meat boiled in water without adding any ingredients. Mean 
aluminium values in the examined samples obtained from raw meat, boiled meat and cooked with adding tomato, onion, salt, spices and with mixing of all the previous additives were $8.89 \pm 3.71,16.91 \pm 8.25,20.44 \pm 3.76$, $19.74 \pm 15.55,20.29 \pm 10.52,24.77 \pm 7.61$ and $24.93 \pm 20.29 \mathrm{mg} / \mathrm{kg}$ wet weight respectively. The effects of cold storage in aluminium pans at different time was also investigated. The aluminium levels in the examined samples were increased by increasing storage time at refrigerator $\left(4^{\circ} \mathrm{C}\right)$ in aluminium vessels. This may be regards to the aluminium migration which seems to depend upon several factors, such as the chemical constituent of food, the duration and the temperature of storage and the addition of any substances that result in dissolution of the metal constituents. However, eating meats prepared in aluminium utensils may carry a risk to the health. The effects of aluminium residues on the public health were discussed.

Key words: Aluminium residues, aluminium utensils, raw meat, cooked meat, food additives

\section{INTRODUCTION}

From the public health of point view eating healthy food and protection of human health against food spoilage, infection, intoxication and risks is the aim of the food hygienest to help human for persistent healthy life. Aluminium toxicity is one of the most important risks to human health. Many possible sources of aluminium intake by the human body as drugs, foods, drinking water and industrial exposure, food is the main route by which the normal daily intake of aluminium occurs. Food cooked in aluminium (Al) vessels or in aluminium foil, can absorb aluminium because $\mathrm{Al}$ dissolves into food and water during the cooking process. The wide use of $\mathrm{Al}$ cook ware because of its favorable physical characteristics and it has excellent corrosion resistance and durability due to the protective oxide layer and easy processing properties (Joshi et al., 2003).

Aluminium content in majority of naturally derived products does not exceed $10 \mathrm{mg} / \mathrm{kg}$ (usually $0.1-1 \mathrm{mg} / \mathrm{kg}$ ). In boiling tests with neutral porridge no migration of aluminium into the test matrix was observed from the pan. When boiling of milk, the leaching of aluminium was 0.2-0.8 $\mathrm{mg} / \mathrm{kg}$. The highest aluminium concentration of $170 \mathrm{mg} / \mathrm{kg}$ was measured in rhubarb juice prepared in the steaming $\mathrm{Al}$ vessel (Liukkonen-Lilia and Piepponen 1992). More accurate data indicates intake of $9 \mathrm{mg}$ per day for teenage and adult females and 12-14 mg per day for teenage and adult males (Pennington, 1988). 
Migration of the aluminium metal was found significantly higher in acidic and aqueous medium in comparison to alcoholic and saline medium. Higher temperature conditions also enhanced the rate of migration of aluminium in acidic and aqueous medium. High fluoride concentration and low $\mathrm{pH}$ were found to enhance the leaching of aluminium more from low quality utensils than from high quality utensils (Hiranandani's, 2007).

longstanding exposure of patients to a high dose of $\mathrm{Al}$ will results in chronic renal failure (Meiri, et al., 1993). Aluminium has also been associated with various degrees of osteomalacia due to Al ions could inhibit different metabolic processes as a result of competition reactions between $\mathrm{Al}$ and other ions such as calcium, magnesium or iron (Macdonald and Martin 1988). Continuous exposure to aluminium over thirty to forty years may cause neurological failures (Alzheimer's disease) where it is absorbed and accumulated in brain tissue (Gauthier et al., 2000; Polizzi et al., 2002; Miu, et al., 2004; Gupta et al., 2005). Moreover, inhibition of total proteins in the serum, cerebral hemisphere and spinal cord enzymes following aluminium toxicity was recorded (Slanina, et al., 1984). Currently the real scientific question is not the amount of aluminium in food but the availability of the aluminium in food and the sensitivity of some population groups to aluminium (Greger, 1992). Hiranandani's, (2007) stated that some people with aluminium allergy may react to medicines packed in aluminium foil especially to acidic medication like aspirin.

This work was highlighted the hygienic effect of Al utensils used in food cooking in Egypt as well as the residual Al level determination in meat cooked in $\mathrm{Al}$ utensils using different food additives.

\section{MATERIALS and METHODS}

Seventy samples of fresh meat were collected from local markets. Samples were divided into seven studies groups, 10 samples of each. The samples were prepared and cleaned to be free from extraneous fat, tendons and major blood vessels.

The first group was kept as raw meat; the other groups were boiled in water using aluminium utensils with different methods (boiling in water without any addition, boiling in water with salt, boiling in water with onion, boiling in water with tomato, boiling in water with spices and boiling in water with all previous additives) until complete cooking.

Samples from each group were finely minced and homogenized (using stainless utensils), and subjected to aluminium determination using the atomic-absorption spectrophotometer (Buck Scientific, Inc., 210VGP, 
Fort Point St., East Norwalk, CT., USA.) by the wet oxidation method, according to AOAC (1990). In addition, a tomato, onion, salt and spices were analyzed for aluminium content before cooking, the estimated levels of aluminium for each sample were calculated as the mean of the metal levels expressed as $\mathrm{mg} / \mathrm{kg}$ based on wet weight sample.

Samples from cooked meat with all additives were stored at $4{ }^{\circ} \mathrm{C}$ in aluminium utensils and analyzed for their aluminium content after $0,6,12$, 24, 48 and $72 \mathrm{hr}$.

The results were analyzed using the Statistical Package for Social Scientists (SPSS) for windows 12.0 (SPSS Inc., Chicago, IL, and USA). Minimum, maximum, mean, standard error and standard deviation of mean were used to describe data.

\section{RESULTS}

Table 1: Statistical analytical results of aluminium content $(\mathrm{mg} / \mathrm{kg}$ wet weight) in raw meat, tomatoes, onion, salt and spices before cooking. $(\mathrm{n}=10)$.

\begin{tabular}{|c|c|c|c|c|c|}
\hline \multirow{2}{*}{$\begin{array}{c}\text { Statistical } \\
\text { analysis }\end{array}$} & \multicolumn{5}{|c|}{ Sample type } \\
\cline { 2 - 6 } & Raw meat & Raw tomato & Raw onion & Salt & Spices \\
\hline Min. & 3.62 & 23.00 & 2.15 & 23.08 & 30.02 \\
\hline Max. & 13.35 & 49.75 & 57.00 & 48.90 & 58.42 \\
\hline Mean \pm SD & $8.89 \pm 3.71$ & $40.11 \pm 11.49$ & $35.08 \pm 16.13$ & $39.54 \pm 8.70$ & $41.61 \pm 12.46$ \\
\hline SE & 1.17 & 3.63 & 5.10 & 2.75 & 3.94 \\
\hline
\end{tabular}

Table 2: Statistical analytical results of aluminium residues $(\mathrm{mg} / \mathrm{kg}$ wet weight) in raw and cooked meat by different methods in aluminium pans. $(n=10)$.

\begin{tabular}{|c|c|c|c|c|c|c|c|}
\hline \multirow{2}{*}{$\begin{array}{c}\text { Statistical } \\
\text { analysis }\end{array}$} & \multirow{2}{*}{ Raw meat } & \multirow{2}{*}{$\begin{array}{c}\text { Boiling in } \\
\text { water }\end{array}$} & & \multicolumn{5}{|c|}{ Tomato } & Onion & Salt & Spices & All additives \\
\cline { 5 - 8 } & & & & & & & \\
Min. & 3.62 & 8.58 & 15.00 & 5.80 & 7.65 & 13.25 & 3.00 \\
\hline Max. & 13.35 & 27.82 & 23.80 & 57.62 & 36.08 & 35.40 & 59.90 \\
\hline Mean \pm SD & $8.89 \pm 3.71$ & $16.91 \pm 8.25$ & $20.44 \pm 3.76$ & $19.74 \pm 15.55$ & $20.29 \pm 10.52$ & $24.77 \pm 7.61$ & $24.93 \pm 20.29$ \\
\hline SE & 1.17 & 2.60 & 1.19 & 4.92 & 3.33 & 2.41 & 6.42 \\
\hline
\end{tabular}


Table 3: Level of aluminium residues $(\mathrm{mg} / \mathrm{Kg}$ wet weight) in meat cooked with all additives kept in aluminium pan during cold storage $\left(4 C^{\circ}\right)$.

\begin{tabular}{|c|c|c|c|c|c|c|}
\hline \multirow{2}{*}{$\begin{array}{c}\text { Statistical } \\
\text { analysis }\end{array}$} & \multicolumn{7}{|c|}{ Cooked meat with all additives } \\
\cline { 2 - 7 } & $0 \mathrm{hs}$ & $6 \mathrm{hs}$ & $12 \mathrm{hs}$ & $24 \mathrm{hs}$ & $48 \mathrm{hs}$ & $72 \mathrm{hs}$ \\
\cline { 2 - 7 } Min. & 3.00 & 17.14 & 39.62 & 77.75 & 122.52 & 178.30 \\
\hline Max. & 59.90 & 38.52 & 65.78 & 150.00 & 253.58 & 336.78 \\
\hline Mean \pm SD & $24.93 \pm 20.29$ & $31.61 \pm 8.10$ & $50.38 \pm 11.61$ & $109.63 \pm 29.39$ & $192.86 \pm 49.31$ & $250.96 \pm 57.27$ \\
\hline SE & 6.42 & 2.56 & 3.67 & 9.30 & 15.59 & 18.11 \\
\hline
\end{tabular}

\section{DISCUSSION}

The analytical results of aluminium content in raw: meat, tomato, onion, salt, and spices are given in Table (1), Al values was expressed in $\mathrm{mg} / \mathrm{kg}$ wet weight. It is shown that spices had the highest level of $\mathrm{Al}$ content $(41.61 \pm 12.46 \mathrm{mg} / \mathrm{kg})$ followed by tomato, salt and onion $(40.11 \pm 11.49,39.54 \pm 8.70$ and $35.08 \pm 16.13 \mathrm{mg} / \mathrm{kg}$, respectively). In this concern, Pennington (1988) and Starska (1993) reported that the major sources of dietary $\mathrm{Al}$ include several with $\mathrm{Al}$ additives (salt, grain products and processed cheese) as well as additives that are naturally high in $\mathrm{Al}$ (spices, herbs and tea).

Data in Table (2) clarified the migration of aluminium from $\mathrm{Al}$ utensils to cooked meat with different methods. Regarding to cooked meat in boiling water without any additives, the mean value was $16.91 \pm 8.25$, it was the lowest level detected in Al content than that cooked with other additives. On the other hand it was higher in $\mathrm{Al}$ level compared with raw meat. In this concern, Gramiccioni et al. (1996) reported that the Al concentration of meat cannelloni prepared in $\mathrm{Al}$ cookware increased by 25\%. Moreover, Liukkonen- Lilja and Piepponen (1992) reported that the $\mathrm{Al}$ content of tap water in $\mathrm{Al}$ pans when reaching boiling point was $0.54 \mathrm{mg} / \mathrm{L}$ and increase with increasing boiling time to $6.3-17 \mathrm{mg} / \mathrm{L}$. Other researchers stated that cooking in $\mathrm{Al}$ utensils resulted in increasing the $\mathrm{Al}$ concentration of food (Fimreite et al., 1997; Yaman et al., 2003; Scancar et al., 2004). In contrast, Diab (2005) stated that Al level in meat with boiling in water $11.34 \pm 4.2 \mathrm{mg} / \mathrm{kg}$ when compared with raw meat $34.039 \pm 0.98 \mathrm{mg} / \mathrm{kg}$ a decrease in the level of $\mathrm{Al}$ was observed. 
The highest values were recorded in meat cooked with all additives followed by spices, tomato, and salt then with onion, gradually; the mean values were $24.93 \pm 20.29,24.77 \pm 7.61,20.44 \pm 3.76,20.29 \pm 10.52$ and $19.74 \pm 15.55 \mathrm{mg} / \mathrm{kg}$, respectively (Table 2). Beside the increase of Al level in cooking with all additives the highest content of Al level was in meat cooked with spices. Similar findings were reported by Lopez et al. (2002) who mentioned that the higher Al concentrations level was detected in foods with greater content of spices, aromatic herbs, certain vegetables, additives and food packaged in $\mathrm{Al}$ vessels.

In the basis of our results, it could be demonstrated that cooking of meat with salt and tomatoes showed high record of Al content and increased the migration of $\mathrm{Al}$ into food, this may be due to the enhancing chemical and/or electrochemical corrosion. These data are in agreement with those reported by Gramiccioni et al. (1996) who reported the highest release of Al into acidic and salted foods from cookware. They added that $\mathrm{Al}$ concentration increased due to chemical corrosion by acids and alkalis during boiling and storage periods in aluminium vessels. Parallel to the present results, Muller et al. (1993) found that high amount of Al migrated into acidic products such as mashed tomatoes during processing in normal $\mathrm{Al}$ pans. The aluminium migration into acidic solvent when heated (at temp. $95 \mathrm{c}^{\circ}$ for $30 \mathrm{~min}$.) was higher than that into tap water (Takeda et al., 1998). Aluminium dissolves faster into acidic foods than into basic foods, it was always unwise to cook acidic foods like tomatoes, tea and coffee in $\mathrm{Al}$ vessels (Hiranandani's, 2007). The Al elution in the presence of sodium chloride was distinctly accelerated by heating; dissolution of $\mathrm{Al}$ was enhanced by addition of sodium chloride but it was reduced by the presence of proteins, amino acid, sugar and cholesterol (Matsushima., et al., 1990). In this respect, Wen (1991) suggested that $\mathrm{Fe} 3+$ and $\mathrm{NaCl}$ being able to promote aluminium leaching.

Results recorded in Table (3) showed an increase of $\mathrm{Al}$ content by increasing storage time at refrigerator $\left(4^{\circ} \mathrm{C}\right)$ in $\mathrm{Al}$ vessels, the meat samples cooked with all additives (tomato, onion, salt, and spices) were stored at $4^{\circ} \mathrm{C}$ in aluminium vessels then analyzed at $0,6,12,24,48$, and 72 $\mathrm{hr}$. The values were $24.93 \pm 20.29,31.61 \pm 8.10,50.38 \pm 11.61,109.63 \pm 29.39$, $192.86 \pm 49.31$ and $250.96 \pm 57.27 \mathrm{mg} / \mathrm{kg}$, respectively. The storage of cooked meat in $\mathrm{Al}$ pans at refrigerator resulted in increased migration of $\mathrm{Al}$ into meat with the storage time. These findings are in accordance with Mei and Yao (1994) who reported that Al concentration increased due to chemical corrosion by acids and alkalis during boiling and storage for short periods in aluminium vessels. In addition, Shuping (1996) stated that electrochemical corrosion when foods are left in contact with $\mathrm{Al}$ vessels 
for long periods, acidic and salty foods and increasing concentrations of complexing ions (organic acids, fluoride ions, $\mathrm{OH}$ ) significantly enhanced the release of aluminium.

It could be concluded after the six methods of cooking that meat cooked in boiling water without any additives appeared to be the best one. In general, addition of tomato or salt resulted in greater migration of aluminium to the cooked meat. Regarding the provisional tolerable daily intake of $1 \mathrm{mg} / \mathrm{kgm}$ body weight per day of the FAO/WHO Expert Committee Food Additives (FAO/WHO, 1994), it can be stated that there is no evident risk to the health of consumer from eating $200 \mathrm{gm}$ of cooked meat prepared in aluminium pan, so it is important to avoid using aluminium pan for storage of food because of the health risk associated with high aluminium intake. Drinking freshly squeezed orange, pineapple, grapefruit, or sweet lime juice can help remove aluminium from the body and help mitigate these problems (Hiranandani's, 2007). In view of this my recommendation for good health and hygiene is to use stainless steel or cast iron cookware and spoons.

\section{REFERENCES}

AOAC (1990): Official Methods of Analysis, $15^{\text {th }}$ ed. Assoc. of Official Analytic Chemists. Washington. DC.

Diab, Omaima, M. (2005): Monitoring of aluminium residues in cooking meat. Assiut Vet. Med. J. 105(51): 100-107.

FAO/WHO. (1994): Summary evaluation performed by the joint FAO/WHO Expert Committee on Food Additives (JECFA).

Fimreite, N.; Hansen, O. and Pettersen, H.C. (1997): Aluminium concentrations in selected foods prepared in aluminium cookware, and its implications for human health. Bulletin of Environ. Contam. and Toxic. 58: 1-7.

Gauthier, E.; Fortier, I.; Courchesne, F.; Pepin, P.; Mortimer, J. and Gauvreau, D. (2000): Aluminium forms in drinking water and risk of Alzheimer's disease. Environ. Research, 84: 234-246.

Gramiccioni, L.; Ingrao, G.; Milana, MR.; Santaroni, P. and Tomassi, G. (1996): Aluminium levels in Italian diets and in selected foods from aluminium utensils. 1: Food Addit. Contam. 13(7):767-74.

Greger, J.L. (1992): Dietary and other sources of aluminium intake. Ciba Found Symp. 169: 26-35.

Gupta, V.B.; Suram, A.; Hegde, M.L.; Zecca, L.; Garruto, R.M. and Ravid, $R$. (2005): Aluminium in Alzheimer's disease: are we still at a 
crossroads? CMLS Cellular and Molecular Life Sciences, 62: 1-16.

Hiranandani's, M. (2007): Cooking foods in aluminium vessels is dangerous. Food Chemistry. 83: 383-386.

Joshi, S.P.; Toma, R.B.; Medora, O. and Connor, K. (2003): Detection of aluminium residue in sauces packaged in aluminium pouches. $\mathrm{J}$. Environ. Sci. Eng. 46(1): 31-8.

Liukkonen-Lilja, H. and Piepponen, S. (1992): Leaching of aluminium from aluminium dishes and packages. Food Addit. Contam. 9(3): 213-23.

Lopez, FE.; Cabrera, C.; Lorenzo, ML. and Lopez, MC. (2002): Aluminium levels in convenience and fast foods: in vitro study of the absorbable fraction. Sci. Total Environ. 2; 300(1-3): 69-79.

Macdonald, T.L. and Martin, K.B. (1988): Aluminium ion in biological systems. Trends Biochemical Science, 13: 15-19.

Matsushima, F.; Meshitsuka, S.; Funakawa, K. and Nose, T. (1990): Effect of sodium chloride, acetic acid and citric acid on the dissolution of aluminium from aluminium cooking utensils. Nippon Eiseigaku Zasski. 45 (5): 964-70.

Mei, l. and Yao, T. (1994): Aluminium concentration of food from using aluminium ware. International J. Environ. Anal. Chem. 50(1).1.

Meiri, H.; Banin, E.; Roll, M. and Rousseau, A. (1993): Toxic effects of aluminium on nerve cells and synaptic transmission. Progress in Neurobiology, 40: 89-121.

Miu, A.C.; Olteanu, A.I. and Miclea, M. (2004): A behavioral and ultra structural Dissection of the interference of aluminium with aging. Journal of Alzheimer's Disease, 6: 315-328.

Muller, JP.; Steinegger, A. and Schlatter, C. (1993): Contribution of aluminium from packaging materials and cooking utensils to the daily aluminium intake. Zlebensm Unters Forsch.197(4):332-41.

Pennington, JA. (1988): Aluminium content of foods and diets. Food Addit. Contam. 5(2): 161-232.

Polizzi, S.; Pira, E.; Ferrara, M.; Bugiani, M.; Papaleo, A. and Albera, R. (2002): Neurotoxic effects of aluminium among foundry workers and Alzheimer's disease. Neurotoxicology, 23: 761-774.

Scancar, J.; Stibilj, V. and Milacic, R. (2004): Determination of aluminium in Slovenian foodstuffs and its leachability from aluminiumcookware. Food Chemistry, 85: 151-157.

Shuping, B. (1996): A model describing the complexing effect in the leaching of aluminium from cooking utensils. Environ. Poll. 92(1): 85 . 
Slanina, P.; Falkeporn, Y.; Frech, W. and Cedrgren, A. (1984): Aluminium concentrations in the brain and bone of rats fed citric acid aluminium citrate or aluminium hydroxide. Fed. Chem. Toxic. 22( 5): 391-394.

Starska, K. (1993): Aluminum in food; U.S. National Library of Medicine and the National Institutes of Health 44(1): 55-63.

Takeda, Y.; Kawamura, Y. and Yamada, T. (1998): Dissolution of aluminium from aluminium foils products in food-simulating solvents. Journal of the Food Hygienic Society of Japan, 39: 178-183.

Wen, W. (1991): Study on factors affecting aluminium leaching from aluminium-utensils. Zhonghua Yu Fang Yi Xue Za Zhi. 25(3): 174-6.

Yaman, M.; Gunes, M. and Bakirdere, S. (2003): Contamination of aluminium from cooking utensils and yogurt containers. Bulletin of Environ. Contam. and Toxic. 70: 437-442. 